\title{
High Th17:Treg ratio may predict complete response to HDIL-2 in the setting of melanoma
}

\author{
Maggie L Diller ${ }^{1 *}$, Ford Mandy ${ }^{2}$, Keith A Delman ${ }^{3}$, David H Lawson ${ }^{3}$ \\ From 30th Annual Meeting and Associated Programs of the Society for Immunotherapy of Cancer (SITC 2015) \\ National Harbor, MD, USA. 4-8 November 2015
}

\section{Introduction}

In vitro and in vivo experiments have demonstrated a potent yet opposite effect of IL-2 on both regulatory $\mathrm{T}$ cells $\left(\mathrm{T}_{\mathrm{REG}}\right)$ and IL-17+CD45RA-CD4+ T cells (Th17). $\mathrm{T}_{\mathrm{REG}}$ cells have been implicated as an important immunoregulator enhancing tumor growth whereas Th17 cells may mediate tumor destruction. This study compares the effect of high-dose IL-2 (HDIL-2) on both the TREG and Th17 compartments in responders and non-responders.

\section{Methods}

Peripheral blood was collected at baseline and at 24, 48, 72 , and 96 hours post-treatment from 6 patients undergoing HDIL-2 therapy under an IRB approved protocol. No patients enrolled received anti-PD-1 or anti-CTLA4 therapies. PBMCs were isolated and underwent intracellular cytokine and extracellular receptor staining for flow cytometry. Statistical analysis was performed using paired student's t tests via Prism 6.0e software.

\section{Results}

5 of 6 patients clinically progressed on HDIL-2 therapy (non-responders, NR), and these patients demonstrated an increase in the frequency of CD25+FoxP3+CD4+ $\mathrm{T}$ cells $\left(\mathrm{T}_{\mathrm{REG}}\right)$ on day 4 of treatment $(4 \%+/-1 \%$ on day 0 to $14 \%+/-6 \%$ on day $4, \mathrm{p}$ value $=0.06)$. A single patient responded to HDIL-2 therapy (complete responder, CR) and demonstrated a decrease in the frequency of $\mathrm{T}_{\mathrm{REG}}$ cells on day 4 of treatment (9\% on day 0 to $7 \%$ on day 4). HDIL-2 increased the frequency of IL-17 + CD45RA-CD4+ T cells (Th17) on day 4 of therapy in all patients analyzed $(0.7 \%+/-0.4 \%$ on day 0 versus $2 \%$ $+/-1 \%$ on day 4 , $\mathrm{p}$ value $=0.04$; Figure 1$)$. Absolute numbers of Th17 cells also demonstrated a statistically

${ }^{1}$ Department of General Surgery, Emory University, Atlanta, GA, USA Full list of author information is available at the end of the article

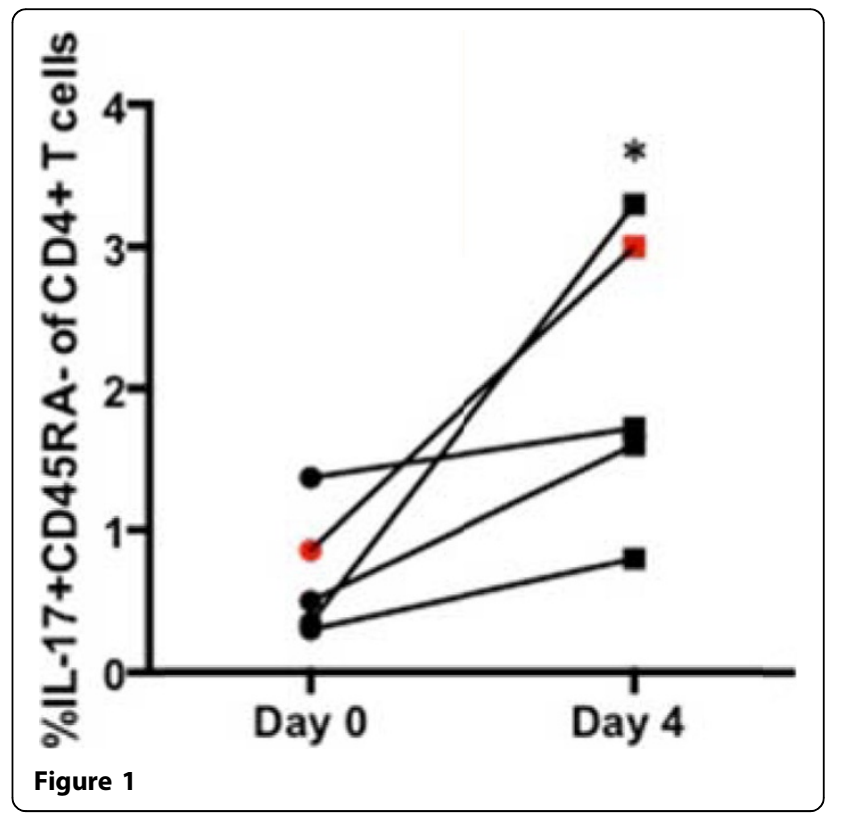

significant increase on day 4 of therapy $(5+/-1 \mathrm{cell} / \mu \mathrm{L}$ on day 0 versus $38+/-24$ cells $/ \mu \mathrm{L}$ on day $4, \mathrm{p}$ value $=0.04$, Figure 2). Subsequent analyses demonstrated a negative Th17: $\mathrm{T}_{\mathrm{REG}}$ ratio on day 4 of HDIL-2 treatment in all non-responders. Importantly, the complete responder demonstrated a positive Th17: $\mathrm{T}_{\mathrm{REG}}$ ratio on day 4 of treatment (Figure 3). The observed difference in cytokine production appeared to be specific to IL-17 as there was no statistically significant change in frequency or total numbers of IFN-g+ or IL-2+CD4+ and CD8+ T cells.

\section{Conclusion}

Our results suggest a distinct immunophenotype indicative of response to HDIL-2. Analysis of peripheral $\mathrm{T}_{\mathrm{REG}}$ and Th17 cell frequencies early in the course of HDIL-2 

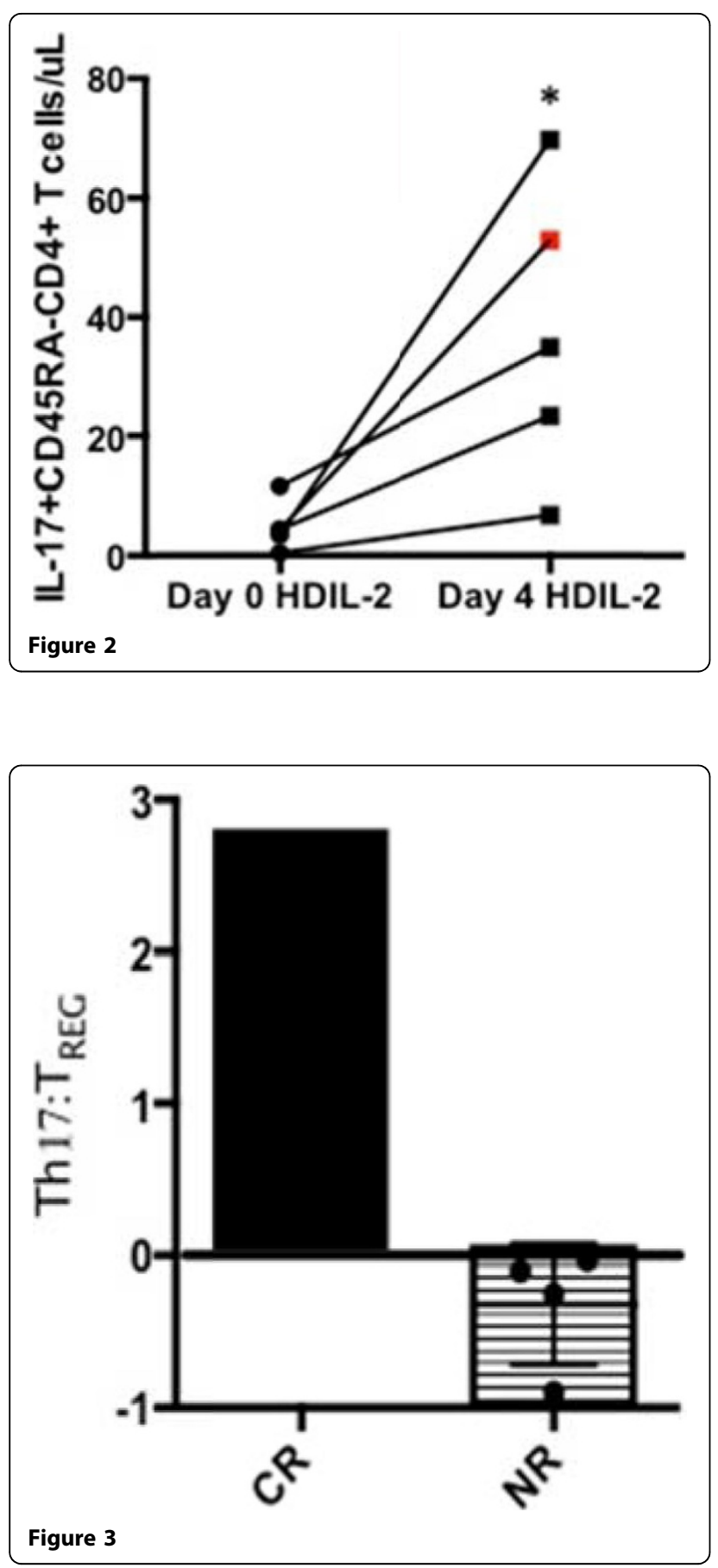

therapy may help identify those patients who would benefit from subsequent cycles.

\section{Authors' details}

${ }^{1}$ Department of General Surgery, Emory University, Atlanta, GA, USA. ${ }^{2}$ Emory University Transplant Center, Atlanta, GA, USA. ${ }^{3}$ Emory University Winship Cancer Institute, Atlanta, GA, USA.

Published: 4 November 2015
doi:10.1186/2051-1426-3-S2-P297

Cite this article as: Diller et al:: High Th17:Treg ratio may predict

complete response to HDIL-2 in the setting of melanoma. Journal for

ImmunoTherapy of Cancer 2015 3(Suppl 2):P297.
Submit your next manuscript to BioMed Central and take full advantage of:

- Convenient online submission

- Thorough peer review

- No space constraints or color figure charges

- Immediate publication on acceptance

- Inclusion in PubMed, CAS, Scopus and Google Scholar

- Research which is freely available for redistribution 